ISSN 25980580

Bioscientia Medicina Volume 3, Issue 4, Page No: 39-44

Available online : www.bioscmed.com

Bio Sc Med 3(4) :39-44

\title{
The Anticancer Activity of Srikaya Leaves Fraction (Annona squamosa L.): An In Vitro Study
}

\author{
Makbruri $^{1 *}$, Irsan Saleh ${ }^{2}$, Rachmat Hidayat ${ }^{3}$ \\ ${ }^{1}$ Department of Anatomy, Faculty of Medicine, Universitas Bengkulu, Bengkulu, Indonesia \\ ${ }^{2}$ Department of Pharmacology, Faculty of Medicine, Universitas Sriwijaya, Palembang, Indonesia \\ ${ }^{3}$ Department of Biology, Faculty of Medicine, Universitas Sriwijaya, Palembang, Indonesia \\ *Corresponding author email: makbruri.amin@gmail.com \\ Received : August $29^{\text {th }} 2019$ \\ Accepted : October $28^{\text {th }} 2019$
}

Background

Abstract

Anticancer drugs are aimed primarily at inhibiting the growth and proliferation of cancer cells. Srikaya leaves (Annona squamosa L.) had been proven to possess various therapeutic effects and potential to be developed as anticancer drugs due to its cytotoxic activity.

Objective Methods

This study aimed to assess the anticancer activity of srikaya leaves (Annona squamosa L.) fraction.

Methanol fraction of srikaya leaves were obtained at concentrations of $500 ; 250 ; 125 ; 62.5 ; 31.25 \mu \mathrm{g} / \mathrm{ml}$. Srikaya methanol fraction and cisplatin as control were given to a plate that was sealed with T47D cells for MTT assay. Identification of compounds in the methanol fraction of srikaya leaves was performed with thin layer chromatography (TLC). Data were collected in the form of absorbance value and half-maximal inhibitory concentration (IC50) value was determined by linear regression. Data analysis was carried out with paired T test, unpaired T test, and ANOVA.

Results

Average percentage of T47D cells viability increased with the decrease in the concentration of srikaya methanol fraction. Obtained IC50 value was $174.25 \mu \mathrm{g} / \mathrm{ml}$ which was quite active and potential to be developed as an anticancer drug. Methanol fraction of srikaya leaves contained secondary terpenoid metabolites, steroids, phenols, flavonoids, alkaloids and tannins. Flavonoid was the dominant metabolites in phytochemical tests and believed to play a major role in cytotoxic activity of srikaya leaves.

Conclusion

Methanol fraction of srikaya leaves possessed the cytotoxic effect on T47D cancer cell line through the role of flavonoid metabolites.

Keywords: srikaya, Annona squamosa, anticancer, T47D cells

\section{Introduction}

Cancer is of the many diseases prominent as the leading cause of burden and mortality in the world. According to World Health Organization (WHO) in 2018, the global cancer burden is 
ISSN 25980580

estimated to have risen to 18.1 million new cases and 9.6 million deaths. The morbidity is one in 5 men and one in 6 women, with a mortality of one in 8 men and one in 11 women. Worldwide, the 5-year prevalence or total survivor within 5 years is estimated to be 43.8 million [1].

Anticancer drugs are aimed primarily at inhibiting the growth and proliferation of cancer cells. Molecular targets for anticancer drugs in breast cancer cells include estrogen receptor (ER), human epidermal growth factor receptor 2 (HER2), and vascular endothelial growth factor (VEGF). The target for induction of apoptosis and anti-apoptotic inhibition involves the p53mitochondrial and TNF-related apoptosis-inducing ligand (TRAIL) receptors, nuclear 2 transcription factors, cell cycle processes, signal transduction and angiogenesis [2].

Srikaya (Annona squamosa L.) had been proven to possess various therapeutic effects [3-8] and potential to be developed as anticancer drugs [9]. This plant contains several active compounds including flavonoids, borneol, camphor, alkaloids, terpenes, saponins, tannins, polyphenols and polyketide compounds [10]. Some previous studies had shown that srikaya plants possessed potential cytotoxic activity [11]. This study was conducted to complement previous research and was carried out only at the cytotoxic test stage. This study was conducted to assess the efficacy of the polar fraction of srikaya leaves (Annona squamosa L.) on cytotoxic activity against T47D cells.

\section{Methods}

This study was an experimental in vitro study using the T47D breast cancer cell line. Srikaya leaves were obtained from the Traditional Medicine Research and Development Center, Tawangmangu, Indonesia. Simplicia of the srikaya leaves were first dried and mashed, then extracted with methanol solvent by maceration for $3 \times 24$ hours. Simplicia filtration and pulp maceration were performed. Macerate was evaporated with a rotary evaporator to obtain the thick extracts. The obtained extract was added by aquadest in 1:1 ratio. $\mathrm{N}$-hexane solvent as much as $200 \mathrm{ml}(5 \mathrm{x} 200 \mathrm{ml})$ was added and then separated with a separating funnel. Ethyl acetate solvent as much as $200 \mathrm{ml}(5 \times 200 \mathrm{ml})$ was added. The n-hexane, ethyl acetate and methanol fractions were obtained. In this study, the test fraction to be explored was methanol. 
ISSN 25980580

Methanol fraction from srikaya leaves was diluted with dimethyl sulfoxide (DMSO) and Dulbecco's modified Eagle's medium (DMEM) to obtain concentrations of 500; 250; 125; 62.5; and $31.25 \mu \mathrm{g} / \mathrm{ml}$. Cisplatin was used with a concentration of 50: 25: 12,5: 6,25: 3,125 $\mu \mathrm{g} / \mathrm{ml}$. Furthermore, the test fraction and cisplatin were given to a plate that was sealed with T47D cells for the 3-(4,5-Dimethylthiazol-2-yl)-2,5-diphenyltetrazolium bromide (MTT) assay. Identification of compounds found in the methanol fraction of srikaya leaves was performed with thin layer chromatography (TLC).

Data were collected in the form of absorbance from enzyme-linked immunosorbent assay (ELISA) reader. From the absorbance values, cytotoxic activity of the test compounds was expressed by half-maximal inhibitory concentration (IC50) values which was determined with linear regression. The IC50 value indicated the concentration value which results in 50\% inhibition of cell proliferation. The cytotoxic activity against cancer cells was classified as "very active" if the IC50 value was $<10 \mu \mathrm{g} / \mathrm{ml}$, "active" if the IC50 value was $10-100 \mu \mathrm{g} / \mathrm{ml}$ and "quite active" if the IC50 value was 100-500 $\mu \mathrm{g} / \mathrm{ml}$ [12]. Data analysis was carried out with paired T test, unpaired T test, and ANOVA.

\section{Results}

Table 1. Efficacy of Srikaya Leaves Fraction against Cancer Cell Line Viability

\begin{tabular}{lll}
\hline No & \multicolumn{1}{c}{ Treatment } & $\begin{array}{c}\text { Cell Line Viability (\%) } \\
\text { Mean } \pm \text { SD }\end{array}$ \\
\hline 1 & MF 500 & $46.78 \pm 0,014^{*}$ \\
\hline 2 & MF 250 & $49.89 \pm 0,016^{*}$ \\
\hline 3 & MF 125 & $59.84 \pm 0,007^{*}$ \\
\hline 4 & MF 62.5 & $62.97 \pm 0,029^{*}$ \\
\hline 5 & MF 31.25 & $65.79 \pm 0,021^{*}$ \\
\hline 6 & CIS 50 & $23.60 \pm 0,070$ \\
\hline 7 & CIS 25 & $38.13 \pm 0,021$ \\
\hline 8 & CIS 12.5 & $56.10 \pm 0,032$ \\
\hline 9 & CIS 6.25 & $61.60 \pm 0,070$ \\
\hline 10 & CIS 3.125 & $63.19 \pm 0,035$ \\
\hline
\end{tabular}

MF: Methanol fraction; CIS: Cisplatin; ${ }^{*} \mathrm{p}<0,05$ vs Cis 3,125 posthoc test 
As shown in Table 1, methanol fraction of srikaya leaves affected the viability of cancer cells. The highest concentration of $500 \mu \mathrm{g} / \mathrm{ml}$ resulted an average viability of $46.77 \%$ and the average percentage of viability increased with a decrease in the concentration of the test fraction at a concentration of $250 \mu \mathrm{g} / \mathrm{ml}(49.89 \%), 125 \mu \mathrm{g} / \mathrm{ml}(59.84 \%), 62.25 \mu \mathrm{g} / \mathrm{ml}(62.97 \%), 31.25$ $\mu \mathrm{g} / \mathrm{ml}(65.79 \%)$, respectively. The obtained IC50 value was $174.25 \mu \mathrm{g} / \mathrm{ml}$. Based on the classification, the IC50 value of methanol fraction of srikaya leaves was quite active and potential to be developed as an anticancer drug.

As exhibited in Table 2, the methanol fraction of srikaya leaves contained secondary terpenoid metabolites, steroids, phenols, flavonoids, alkaloids and tannins. Flavonoid was the dominant metabolites in phytochemical tests and believed to play a major role in cytotoxic activity of srikaya leaves.

Tabel 2. Phytochemical Analysis of Srikaya

\begin{tabular}{cll}
\hline Fraction & \multicolumn{1}{c}{ Spot Colors } & \multicolumn{1}{c}{ Metabolite } \\
\hline Methanol Fraction & $\begin{array}{l}\text { Purple, yellow, dark } \\
\text { yellow and brown }\end{array}$ & $\begin{array}{l}\text { Terpenoid, steroid, phenol } \\
\text { flavonoid, alkaloid and tannin }\end{array}$ \\
\hline
\end{tabular}

\section{Discussion}

Flavonoid compounds are known to possess the ability to induce apoptosis. Apoptosis as the programmed cell death plays an important role in the process of cancer regulation. The mechanism of flavonoid in inducing apoptosis is through the inhibition of DNA topoisomerase I/II activity, modulation of signaling pathways, decreased expression of Bcl-2 and Bcl-XL genes, increased expression of Bax, Bak and p53 genes, and activation of endonuclease [13, 14]. Flavonoids were the main compounds capable of spurring apoptosis with a variety of mechanisms in the methanol extract of kenikir leaves (Cosmos caudatus Kunth) which had cytotoxic properties against T47D cells with IC50 of $344.91 \mu \mathrm{g} / \mathrm{ml}$. A study showed apoptotic death of myeloma cancer cells due to the influence of the chloroform fraction of papaya leaves (Carica papaya L.) with the main content of alkaloids allegedly through the initial stages of inhibiting the enzyme of DNA Topoisomerase II. With the inhibition of DNA topoisomerase enzyme activity, the process of the bonding between the enzyme and the DNA of the cancer cell was prolonged, protein linked DNA 
ISSN 25980580

breaks (PLDB) was formed, resulted in DNA fragmentation or damage to cancer cells and subsequently affected the cancer cell replication process [15-18].

\section{Conclusion}

Methanol fraction of srikaya leaves possessed the cytotoxic effect on T47D cancer cell line through the role of flavonoid metabolites.

\section{References}

1. World Health Organization. Latest global cancer data: Cancer burden rises to 18.1 million new cases and 9.6 million cancer deaths in 2018 (Press Release). Geneva, Switzerland: International Agency for Research on Cancer; 2018.

2. Schlotter CM, Vogt U, Allgayer H, Brandt B. Molecular targeted therapies for breast cancer treatment. Breast Cancer Res 2008; 10(4): 211.

3. Deshmukh AB, Patel JK. Aqueous extract of Annona squamosa (L.) ameliorates renal failure induced by 5/6 nephrectomy in rat. Indian J Pharmacol 2011; 43(6): 718-21.

4. Kalidindi N, Thimmaiah NV, Jagadeesh NV, Nandeep R, Swetha S, Kalidindi B. Antifungal and antioxidant activities of organic and aqueous extracts of Annona squamosa Linn. leaves. J Food Drug Anal 2015; 23(4): 795-802.

5. Panda S, Kar A. Annona squamosa seed extract in the regulation of hyperthyroidism and lipidperoxidation in mice: possible involvement of quercetin. Phytomedicine 2007; 14(12): 799805 .

6. Raj DS, Vennila JJ, Aiyavu C, Panneerselvam K. The hepatoprotective effect of alcoholic extract of Annona squamosa leaves on experimentally induced liver injury in Swiss albino mice. Int J Integr Biol 2009; 5: 182-6.

7. Kaleem M, Medha P, Ahmed QU, Asif M, Bano B. Beneficial effects of Annona squamosa extract in streptozotocin-induced diabetic rats. Singapore Med J 2008; 49: 800-4.

8. Dholvitayakhun A, Trachoo N, Sakee U, Cushnie TP. Potential applications for Annona squamosa leaf extract in the treatment and prevention of foodborne bacterial disease. Nat Prod Commun 2013; 8(3): 385-8. 
ISSN 25980580

9. Chen Y, Xu SS, Chen JW, Wang Y, Xu HQ, Fan NB, et al. Anti-tumor activity of Annona squamosa seeds extract containing annonaceous acetogenin compounds. J Ethnopharmacol 2012; 142(2): 462-6.

10. Ma C, Chen Y, Chen J, Li X, Chen Y. A Review on Annona squamosa L.: Phytochemicals and Biological Activities. Am J Chin Med 2017; 45(5): 933-64.

11. Wang DS, Rizwani GH, Guo H, Ahmed M, Ahmed M, Hassan SZ, et al. Annona squamosa Linn: cytotoxic activity found in leaf extract against human tumor cell lines. Pak J Pharm Sci 2014; 27(5): 1559-63.

12. Weerapreeyakul N, Nonpunya A, Barusrux S, Thitimetharoch T, Sripanidkulchai B. Evaluation of the anticancer potential of six herbs against a hepatoma cell line. Chin Med 2012; 7: 15 .

13. Ren W, Qiao Z, Wang H, Zhu L, Zhang L. Flavonoids: promising anticancer agents. Med Res Rev 2003; 23(4): 519-34.

14. Ren W, Qiao Z, Wang H, Zhu L, Zhang L. Flavonoids: Promising Anticancer Agents. Med Res Rev 2003; 23 (4): 519-34.

15. Koleva II, van Beek TA, Linssen JP, de Groot A, Evstatieva LN. Screening of plant extracts for antioxidant activity: a comparative study on three testing methods. Phytochem Anal 2002; 13: $8-17$.

16. Nandhakumar E, Indumathi P. In vitro antioxidant activities of methanol and aqueous extract of Annona squamosa (L.) fruit pulp. J Acupunct Meridian Stud 2013; 6: 142-8.

17. Pandey VK, Giri IC, Prakashdeep, Singh S, Srivastava A. Pharmacognostical and physiochemical study on the leaves of Annona squamosa Linn. Int J Res Pharm Sci 2014; 4: $8-12$.

18. Taraphdar AK, Roy M, Bhattacharya RK. Natural products as inducers of apoptosis: Implication for cancer therapy and prevention. Curr Sci 2001; 80(11): 1391. 